\title{
Contributions of the Ecological Approach to the Neuropsychology of Executive Functions
}

\author{
Nicolle Zimmermann \\ Pontifícia Universidade Católica do Rio Grande do Sul, Programa de Pós-Graduação \\ em Psicologia, Porto Alegre, Rio Grande do Sul, Brasil, \\ Universidade Federal do Rio de Janeiro, Programa de Pós-graduação em Medicina \\ (Radiologia), Rio de Janeiro, Rio de Janeiro, Brasil, \\ Instituto Estadual do Cérebro Paulo Niemeyer, Rio de Janeiro, Rio de Janeiro, Brasil \\ Caroline de Oliveira Cardoso \\ Pontifícia Universidade Católica do Rio Grande do Sul, Porto Alegre, \\ Rio Grande do Sul, Brasil \\ Universidade Feevale, Faculdade de Psicologia, Novo Hamburgo, \\ Rio Grande do Sul, Brasil \\ Renata Kochhann \\ Geise Jacobsen \\ Rochele Paz Fonseca ${ }^{1}$ \\ Programa de Pós-Graduação em Psicologia da Pontifícia Universidade Católica \\ do Rio Grande do Sul, Porto Alegre, Rio Grande do Sul, Brasil
}

\begin{abstract}
Neurocognitive assessment involves several different types of processes, techniques and instruments. Traditionally, clinical and/or standardized methods have been the most extensively used in neuropsychological research and clinical practice. Ecological instruments are characterized by the standardized administration of tasks with similar cognitive demands to those observed in everyday situations. Although executive functions are often required in daily living tasks, the lack of a consensus as to their theoretical definition has posed several hurdles to their assessment and rehabilitation. The aim of this paper was to present the contributions of an ecological neuropsychological approach to assessment, rehabilitation, and neuroimaging, while discussing the theoretical implications of these processes on the neuropsychology of executive functions. This was achieved through a non-systematic review of classical and contemporary literature on ecological assessment tools. The use of an ecological approach has contributed to the understanding and assessment of functional impairment, as well as to the development of rehabilitation programs focusing on practical daily living activities, allowing for a clearer understanding of the neural correlates of complex environmental and individual factors, and for a more thorough reassessment of the validity of theoretical models of executive functions .
\end{abstract}

Keywords: Cognitive processes, cognitive neuropsychology, neuropsychological tests.

1 Mailing address: Pontifícia Universidade Católica do Rio Grande do Sul, Av. Ipiranga, 6681, Prédio 11, $9^{\circ}$ andar, sala 932, Porto Alegre, RS, Brasil 90619-900. E-mail: nicolle.zimmermann@gmail.com, carolineocardoso@ yahoo.com.br, renata.kochhann@gmail.com, geisejacobsen@gmail.com and rochele.fonseca@pucrs.br Apoio financeiro: Coordenação de Aperfeiçoamento de Pessoal de Nível Superior (CAPES), Conselho Nacional de Desenvolvimento Científico e Tecnológico (CNPq). 


\section{Contribuições da Abordagem Ecológica na Neuropsicologia das Funções Executivas}

\section{Resumo}

A avaliação neurocognitiva é composta por diferentes tipos de processos, técnicas e instrumentos. Tradicionalmente, recursos clínicos e/ou padronizados têm sido os de maior eleição na clínica e pesquisa neuropsicológica. Os instrumentos ecológicos são caracterizados pela forma padronizada de aplicação associada a tarefas que simulam situações diárias de demanda cognitiva. As funções executivas são amplamente requeridas nas tarefas cotidianas complexas. Além disso, a falta de consenso teórico sobre seus modelos traz um conjunto de problemáticas ao trabalhar com essas funções. O objetivo do presente artigo é apresentar as contribuições da abordagem ecológica para as áreas de avaliação, reabilitação, neuroimagem e, subjacente a todas essas, algumas reflexões teóricas da neuropsicologia das funções executivas. Trata-se de uma revisão não sistemática da literatura baseada na consulta em artigos clássicos e contemporâneos que utilizaram ferramentas de abordagem ecológica. As contribuições dessa abordagem são a busca por uma melhor compreensão de déficits funcionais (avaliação); por uma reabilitação com foco em objetivos práticos da vida diária; a possibilidade de compreensão dos correlatos neurais em settings complexos dependentes de fatores pessoais e ambientais; e a necessidade de reavaliação da validade de modelos teóricos das funções executivas a partir dessas evidências.

Palavras-chave: Processos cognitivos, Neuropsicologia Cognitiva, testes neuropsicológicos.

\section{Aportes del Enfoque Ecológico a la Neuropsicología de las Funciones Ejecutivas}

\section{Resumen}

La evaluación neurocognitiva es compuesta por diferentes tipos de procesos, técnicas y instrumentos. Tradicionalmente, recursos clínicos y/o estandarizados son los de mayor elección en la clínica y la pesquisa neuropsicológica. Los instrumentos ecológicos son caracterizados por una manera estandarizada de aplicación asociada a las tareas que simulan situaciones del cotidiano de demanda cognitiva. Las funciones ejecutivas son en general requeridas en las tareas cotidianas complejas. Además, la falta de consenso teórico sobre suyos modelos tiene un conjunto de problemáticas al trabajar con estas funciones. El objetivo del presente artigo es presentar las contribuciones de la enfoque ecológico para las áreas de evaluación, rehabilitación, neuroimagen e, subyacente a todas esas, algunas reflexiones teóricas de la neuropsicología de las funciones ejecutivas. Es una revisión no sistemática de la literatura basada en la consulta en artículos clásicos y contemporáneos que utilizaron las herramientas del enfoque ecológico. Las contribuciones de esa abordaje son la busca por una mejor comprensión de déficits funcionales (evolución); por una rehabilitación con foco en objetivos prácticos de la vida cotidiana; la posibilidad de comprensión de los correlatos neuronales en settings complejos dependientes de factores personales y ambientales; y la necesidad de re-valuación de la validad de los modelos teóricos de las funciones ejecutivas de esas evidencias.

Palabras clave: Procesos cognitivos, neuropsicología cognitiva, testes neuropsicológicos.

The establishment of neuropsychology as an independent area of research has followed the developmental trajectory of other areas of neuroscience (Marshall \& Fink, 2003), such as neurology, radiology, psychiatry, cognitive psy- chology, and speech therapy. The first major breakthroughs in neuropsychological investigation resulted from attempts to establish relationships between the location of brain lesions and their resulting cognitive/linguistic impairments 
(as the ones from Broca and Wernicke; Cubelli, 2005; Lorch, 2011). However, recent advances in neuroimaging, behavioral diagnoses, and in our understanding of the relationship between brain and behavior have challenged traditional quantitative and experimental methods in neuropsychological practice.

As a result of these developments, the contributions of neuropsychological assessment to the identification of deficits which could be easily reported by patients began to be questioned (Witsken, D'Amato, \& Hartlage, 2008). Additionally, advances in functional neuroimaging techniques have also led to the revision of localizationist theories of brain function (Marshall \& Fink, 2003), corroborating Luria's early models of cerebral functioning. At the same time, a shift toward the study of healthy or non-brain-damaged populations (Peña-Casanova et al., 2009), individuals with psychiatric disorders (Periáñez et al., 2007), and patients with other diseases such as systemic lupus erythematosus (Appenzeller, Faria, Marini, Costallat, \& Cendes, 2006) and Human Immunodeficiency Virus (Ances, Ortega, Vaida, \& Heaps, 2013) was also observed in the neuropsychological literature. These new areas of study have been considered by some authors to represent the "new frontiers" of neuropsychological study (VerdejoGarcía \& Tirapu-Ustárroz, 2012).

More recently, difficulties associated with the use of neuropsychological assessment formal tests to identify the causes of complaints reported by patients (Chan, Shum, Toulopoulou, \& Chen, 2008; Chaytor \& Schmitter-Edgecombe, 2007) have given rise to a new area of study in neuropsychology, consisting of the development and use of ecological tools for neuropsychological assessment and rehabilitation (Chaytor \& Schmitter-Edgecombe, 2003). The academic community has made significant strides in the construction and adaptation of ecological tools for cognitive assessment, although more recently, there has also been a tendency toward the application of ecological theories to areas beyond neuropsychological assessment itself. Recent studies have sought to integrate the knowledge obtained from methods of the ecological study of neuropsychological function to the theoretical framework of neuropsychological science. Therefore, in this article, we aimed to perform a non-systematic review of current and classical literature with the aim of presenting some aspects of ecological neuropsychological models and their applications to the neuropsychological assessment, rehabilitation, neuroimaging and, consequently, to the explanatory theories of executive functions.

\section{Categorization of Neuropsychological Assessments Tools}

The neuropsychological assessment process consists of a series of steps which are continually redesigned as data is collected regarding the patient's performance and functional ability. The final goal of the evaluation is to understand the cognitive processes underlying the patient's functional impairments and/or complaints. In addition to dividing neuropsychological assessment tools according to their qualitative and quantitative nature, it is possible to classify these methods/tools as standardized, functional, clinical, or ecological (Fonseca et al., 2012; Lezak, Howieson, Bigler, \& Tranel, 2012).

Standardized tools involve systematic application, scoring, and interpretation procedures, are often evaluated based on their psychometric properties, and include comparison norms drawn from individuals without brain damage or dysfunction. Functional tools aim to assess patient performance on daily routine tasks, and include interview and observation techniques, assessment scales for daily activities and the performance of specific tasks. Clinical tools are created or adapted for each patient based on the practitioner's knowledge of models of cognitive functioning. Such tasks can be developed based on the manipulation and control of the quality/quantity of the items, rules, difficulty levels, time limits, and other features of standardized assessment tools. This approach allows for the compensation of the limitations associated with exclusive reliance on standardized assessment methods.

Finally, ecological tools combine principles and methods from both standardized and 
functional assessments in an attempt to develop tools which use standardized administration and scoring procedures but also simulate everyday situations and neurocognitive demands. The concept of ecological validity was first defined by Brunswik (1955) as an experimental setup whose results could be generalized to real world settings or events. For an instrument to be considered ecologically valid, it must display one of the two following features: verisimilitude (how much it theoretically resembles the cognitive processes recruited by a routine activity) and veridicality (how much an instrument is related to functional measures; Wood \& Liossi, 2006). Therefore, while "ecological" neuropsychological models first arose as a way to validate assessment instruments, they have now expanded to comprise several technical principles involved in the development of assessment tools.

In a publication discussing the theoretical issues associated with ecological validity research, Chaytor and Schmitter-Edgecombe (2003) suggested that the following features be observed when evaluating or developing ecological assessment instruments: (a) Environment: it is important to consider, in addition to what the patient actually does, what he could do under different circumstances, since certain features of the environment and experimental context can negatively bias performance; (b) Constructs: the lack of consensus as to the constructs assessed by certain standardized instruments and the absence of a satisfactory theoretical description of some cognitive functions makes it difficult to select the ecological measures which would be most suitable for the evaluation of specific cognitive skills on day-to-day tasks, or the formal assessment instruments to which these ecological tools would be most likely to correlate ; (c) Behavior sample: the assessment process is restricted to a single environment, and may fail to take into account the behavioral alterations which may occur over time and in response to different settings; (d) Compensatory strategies: if the clinician does not allow or stimulate the use of compensatory strategies during the assessment process, the patient's performance may not reflect their actual potential to successfully com- plete real-life tasks; (e) Non-cognitive factors: emotional, behavioral, and physical features, as well as premorbid functioning and environmental demands, can all reduce the equivalence between performance in ecological tasks and the patient's daily functioning. In spite of the abundance of studies on standardized and functional assessment techniques (Belleville, Rouleau, \& Van der Linden, 2006; Kounti, Tsolaki, \& Kiosseoglou, 2006), there still appears to be a lack of published literature on the development and adaptation of ecological assessment tools.

\section{Ecological Assessment of Executive Functions}

The assessment of executive functions has received special attention in the literature due to the difficulties in reaching a consensus as to their theoretical and operational bases (Diamond, 2013). According to Barkley, (2012) one of the main problems associated with the assessment of EF using standardized experimental techniques is their lack of reliability and predictive and ecological validity. These ideas were also corroborated by Sbordone (2010). Such findings have led a growing number of authors to conclude that formal instruments may not be able to adequately assess EF. In an attempt to clarify this issue, Burgess et al. (2006) proposed a taxonomy which differentiates the construct of EF from its cognitive operations and behavioral function. The construct refers to the theoretical definition of EF, which has been developed based on research findings; cognitive operations consist of the hypothetical steps in a cognitive process, which cannot be directly observed; and the behavioral functions are the operations which can be observed through behavior. In spite of such efforts to define EF, the nature of these processes is still unknown, and some authors have suggested that certain components of EF may only appear or be manifested in real-world settings (Barkley, 2012). Therefore, neuropsychology moved on from defining theoretical constructs based on experimental tasks to a different approach, based on an ecological perspective: the function is first observed and studied in its natural environment, 
so that this data can then be used to establish its theoretical definition (Burgess et al., 2006). This view has allowed for the development of new perspectives in neuropsychological theory and research.

As part of this new line of research, Cuberos-Urbano, Caracuel, Bateman, Vilar-López, and Verdejo-García (2013) conducted a study of the assessment of executive dysfunction using ecological instruments. The authors performed a predictive analysis of issues in daily functioning using the Dysexecutive Questionnaire and the Frontal System Behavior Scale together with scores obtained on the ecological Multiple Errands Test. Apathy and executive dysfunction were correlated with failures in the task; disinhibition was associated with rule violation; intentionality was correlated with both rule violation and failure to complete the tasks (difficulties in planning or goal directed behavior). The authors also noted that, although intentionality is a critical skill for patient functioning, it is rarely evaluated by traditional assessment instruments. Stuss and Alexander (2007) also defined intentionality as a key component of energization, an important frontal lobe task. Therefore, it appears that, while ecological tests may be able to assess functional impairment in daily activities, traditional standardized instruments may be unable to achieve such a goal (Chaytor, SchmitterEdgecombe, \& Burr, 2006; Koerts et al., 2012).

A similar conclusion has been reached with regard to the assessment of inhibitory control. Diamond (2013), for instance, has reported that the results obtained by children in experimental measures of inhibition are clearly different from those seen reported in behavioral questionnaires. Such findings were also reported by Toplak, West, and Stanovich (2013) in a review of 20 studies which assessed EF using both questionnaires and behavioral tasks. The authors concluded that these assessment techniques evaluated distinct cognitive levels, although this hypothesis is little discussed and poorly understood in the neuropsychological literature on EF. Studies have also revealed discrepancies between the results obtained by assessment instruments across different clinical populations. Shimoni, Engel-
Yeger and Tirosh (2012) investigated whether the use of EF in daily activities could be assessed in controlled settings. Their results indicated that metacognition may be suitable for laboratory assessment, while alterations in behavior regulation in daily living could not be observed in any of the cognitive instruments used.

Studies reveal significant differences between the use of ecological and experimental tasks in the assessment of EF. Thus, investments in the former could have significant implications for the theoretical and methodological development of the construct of EF. Some of the most frequently used ecological instruments to assess EF are described below, while the questionnaires and scales used for this purpose are presented in Table 1. Although ecological assessment is not a new theme in the neuropsychological literature, it appears that approximately half of the total number of articles published on the topic were issued within the past five years. Therefore, this area of research can be still considered a target for technological innovation in neuropsychological practice and research.

Behavioral Assessment of the Dysexecutive Syndrome (BADS; Wilson, Alderman, Burgess, Emslie, \& Evans, 1996). This assessment battery consists of subtests and questionnaires which assess cognitive flexibility (Rule Shift Card), problem solving (Action Program Test), behavior regulation and planning (Key Search Test, Zoo Map Test, Modified Six Elements Test), as well as judgment and estimation (Temporal Judgment Test). The dysexecutive questionnaire contains questions which are answered by the patients and their caregivers. The instrument is currently under adaptation and validation for use in the Brazilian population (Macuglia, Rossatto, Almeida, \& Giacomoni, 2012).

Multiple Errands Test (MET; Shallice \& Burgess, 1991). The MET consists of simple tasks (e.g., buying bread, being in a specific place at a given time) which must be accomplished following a list of rules (e.g., spending as little money as possible, completing the tasks in a particular order, and relying only on a previously defined set of stimuli, such as the purchased items and a watch, to guide patient 
performance). Several versions of the MET have also been developed, such as a reduced version of the task (Alderman, Burgess, Knight, \& Henman, 2003) and an adaptation of the MET for use in hospitals (Knight, Alderman, \& Burgess, 2002). The latter consists of buying three items, getting an item at reception, using the telephone in the hospital and sending a letter to a certain address to collect specific pieces of information, and meeting with the examiner after 20 minutes to inform whether they were able to successfully complete the task.

Hotel Task (Manly, Hawkins, Evans, Woldt, \& Robertson, 2002). This instrument includes five activities commonly performed in a hotel. Initially, the patient is told that the time they will be given will not be sufficient to complete all tasks, and that their main goal should be to perform at least part of each task. The five activities included in the Hotel Task consist of the following: organizing guest accounts, sorting out coins, searching for telephone number in a phone book, organize nametags for a meeting, and reviewing the new advertising brochure for the hotel. This task is currently being adapted for use in Brazilian Portuguese (Cardoso, Zimmermann, et al., 2013).

Executive Secretarial Task (EST; Spikman et al., 2007). In this task, participants are placed in a room with several office supplies (phone, calendar, calculator, etc.) and are asked to organize, initiated and perform a series of tasks, some of which have specific time limits. The tasks include: filling out zip codes on envelopes and posting letters at pre-determined times, searching for restaurants in a phone book, and organizing a travel schedule. This test does not involve the use of explicit cues to inform participants as to how and when the tasks must be performed.

Iowa Gambling Task (IGT; Bechara, Damasio, Damasio, \& Anderson, 1994). This computerized instrument is much like a real life situation of decision making under uncertainty. The IGT consists of a game in which the participant must select cards from four decks, each of which is associated with a different pattern of gains or losses throughout the game (Bechara, 2007; Bechara et al., 1994). Individuals are unaware as to which decks are advantageous or disadvantageous, so that, in order to successfully perform the task, individuals must learn to avoid the disadvantageous decks based on the emotional feedback (somatic markers) produced during the task. The instrument was adapted for use in the Brazilian population (Malloy-Diniz et al., 2008; Schneider \& Parente, 2006), and has been found to be both a valid (Carvalho et al., 2012) and reliable (Cardoso et al., 2010) tool for the assessment of decision making in this population.

Table 1

Executive Functions Questionnaires and Scales

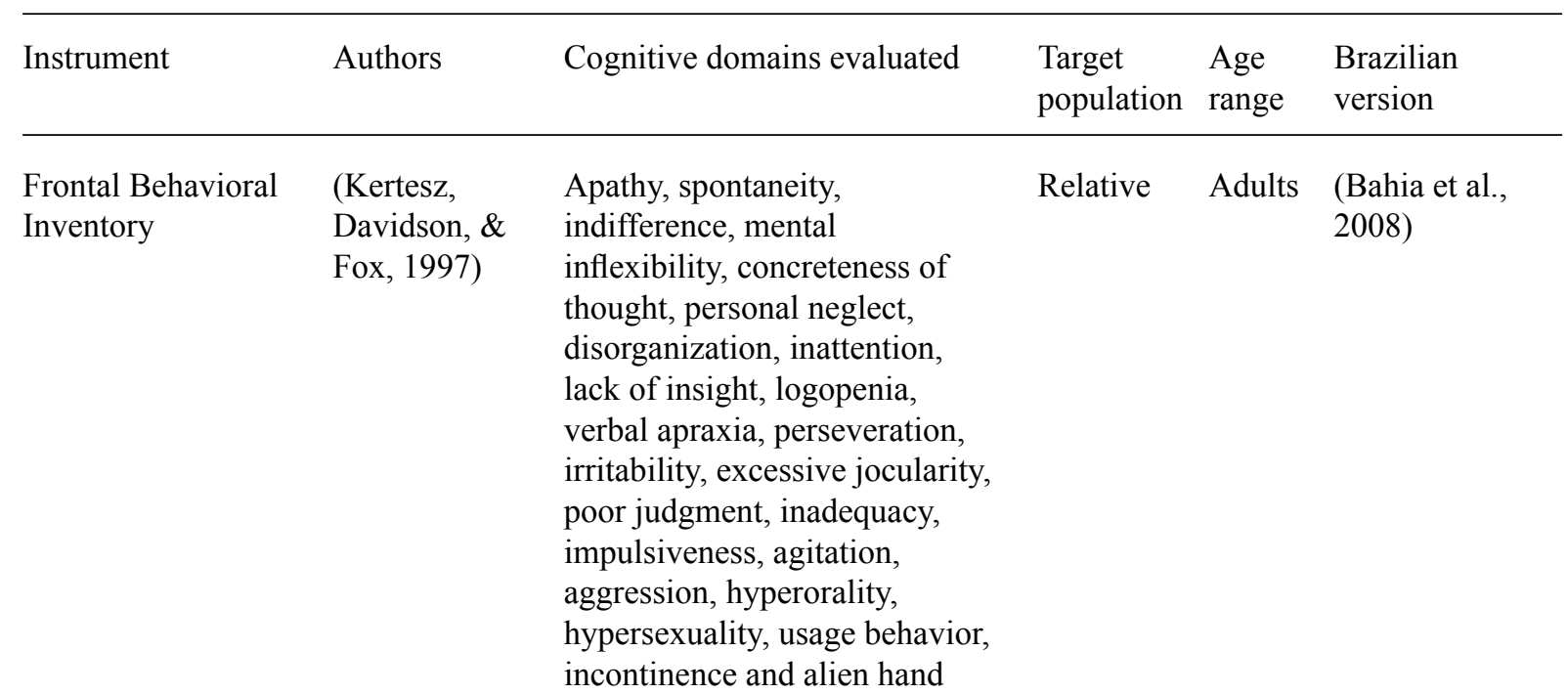




\begin{tabular}{|c|c|c|c|c|c|}
\hline $\begin{array}{l}\text { Behavioral } \\
\text { Inhibition Scale }\end{array}$ & $\begin{array}{l}\text { (Carver \& } \\
\text { White, 1994) }\end{array}$ & $\begin{array}{l}\text { Self-awareness, sensitivity } \\
\text { to stimuli of punishment, } \\
\text { introversion and social anxiety } \\
\text { in general }\end{array}$ & Relatives & Adults & Not found \\
\hline $\begin{array}{l}\text { Patient Competency } \\
\text { Rating Scale }\end{array}$ & $\begin{array}{l}\text { (Prigatano, } \\
1986)\end{array}$ & $\begin{array}{l}\text { Awareness of their cognitive, } \\
\text { behavioral and emotional } \\
\text { competence presented by patient. }\end{array}$ & $\begin{array}{l}\text { Patient } \\
\text { and } \\
\text { relatives }\end{array}$ & Adults & $\begin{array}{l}\text { (Zimmermann, } \\
\text { de Pereira, \& } \\
\text { Fonseca, 2014) }\end{array}$ \\
\hline $\begin{array}{l}\text { Melbourne } \\
\text { Decision Making } \\
\text { Questionnaire }\end{array}$ & $\begin{array}{l}\text { (Mann, } \\
\text { Burnett, } \\
\text { Radford, \& } \\
\text { Ford, 1997) }\end{array}$ & $\begin{array}{l}\text { Vigilance, hypervigilance, } \\
\text { procrastination, buck-passing }\end{array}$ & Patient & Adults & $\begin{array}{l}\text { (Cardoso, } \\
\text { Branco, Cotrena, } \\
\text { \& Fonseca, } \\
\text { 2013) }\end{array}$ \\
\hline
\end{tabular}

The ecological assessment of attention and prospective memory has also been extensively studied. Some used of the tools to assess these processes also involve the use of EF. The scales available for the assessment of prospective memory and attention are presented in Table 2, and the tests used to evaluate these processes are described below.

The Behavioral Inattention Test (Wilson, Cockburn, \& Halligan, 1987). This instrument contains both conventional and behavioral subtests. All subtests assess behavioral aspects of daily living, such as the scanning of three pictures (plate of food, bathroom sink, and a living room); telephone dialing; menu reading; article reading; telling and setting time; coin sorting; address and sentence copying; map navigation and card sorting (Hartman-Maeir \& Katz, 1995).

Test of Everyday Attention (Robertson, Ward, Ridgeway, \& Nimmo-Smith, 1994). The instrument involves the performance of the following subtests: map searching (participants must search for symbols on a colorful map); Elevator counting (participants are asked to pretend they are in an elevator whose floor indicators are broken, and are asked to figure out the floor at which they have arrived by counting a series of tones presented via audio); Elevator counting with distraction (participants must count the lower tones that simulate the elevator indicators while ignoring high-pitched tones); Visual elevator (participants must count up and down as they follow a series of visually presented "doors" in the elevator); Auditory elevator (participants must know which floor they are on while lift goes up and down by accompanying an audio signals); Telephone search (participants must look for target symbols while searching for entries in a telephone directory); Dual telephone search task (participants must search for entries in the phone book while counting sequences of auditory tones).

The Rivermead Behavioral Memory Test (RBMT; Wilson, Cockburn, \& Baddeley, 1985). This instrument evaluates memory using tasks which simulate everyday activities. The RBMT includes subtests such as remembering the names of people in a photograph; observing and remembering the location in which two of the patient's belongings were hidden; remembering an appointment when an alarm sounds; remembering a newspaper report immediately and 20 minutes after reading it; recognizing faces in photographs; remembering the route taken by the examiner to walk between fixed points in the evaluation room immediately and $10 \mathrm{~min}$ utes after the route is demonstrated; delivering a message while performing the route recall task; temporal and spatial orientation, and recognizing familiar pictures among new and unfamiliar ones. All instructions are provided to the patients before the tasks are performed. The extended version of the task (Wilson et al., 1999) has a higher level of difficulty, as it contains twice the amount of information as the short version of the task. The Brazilian version of the instrument (Oliveira \& Schmidt, 1999) has proved to be suitable for identifying memory decline in older adults (Yassuda et al., 2010). 
Table 2

Memory Questionnaires and Scales

\begin{tabular}{|c|c|c|c|c|c|}
\hline Instrument & Authors & $\begin{array}{l}\text { Cognitive domains } \\
\text { evaluated }\end{array}$ & $\begin{array}{l}\text { Target } \\
\text { population }\end{array}$ & Age range & $\begin{array}{l}\text { Brazilian } \\
\text { version }\end{array}$ \\
\hline $\begin{array}{l}\text { Prospective and } \\
\text { Retrospective Memory } \\
\text { Questionnaire (PRMQ) }\end{array}$ & $\begin{array}{l}\text { (Smith, Sala, Logie, } \\
\text { \& Maylor, 2000) }\end{array}$ & $\begin{array}{l}\text { Prospective and } \\
\text { retrospective } \\
\text { memory }\end{array}$ & Patient & $\begin{array}{l}\text { Adults/ } \\
\text { elderly }\end{array}$ & $\begin{array}{l}\text { (Benites \& } \\
\text { Gomes, 2007) }\end{array}$ \\
\hline $\begin{array}{l}\text { Teste de Percepção } \\
\text { Subjetiva de Memória } \\
\text { (MAC-Q) }\end{array}$ & $\begin{array}{l}\text { (Crook, Feher, \& } \\
\text { Larrabee, 1992) }\end{array}$ & $\begin{array}{l}\text { Current memory } \\
\text { as compared to } \\
\text { when patient } \\
\text { was } 40 \text { years-old }\end{array}$ & Patient & Elderly & $\begin{array}{l}\text { (Mattos et al., } \\
\text { 2003) }\end{array}$ \\
\hline $\begin{array}{l}\text { Everyday Memory } \\
\text { Questionnaire }\end{array}$ & $\begin{array}{l}\text { (Sunderland, Harris, } \\
\text { \& Baddeley, 1983) }\end{array}$ & $\begin{array}{l}\text { Subjective } \\
\text { perception of } \\
\text { everyday memory } \\
\text { failures }\end{array}$ & Patient & Adults & Not found \\
\hline $\begin{array}{l}\text { Divided Attention } \\
\text { Questionnaire }\end{array}$ & $\begin{array}{l}\text { (Tun \& Wingfield, } \\
\text { 1995) }\end{array}$ & Divided attention & Patient & Adults & Not found \\
\hline $\begin{array}{l}\text { Adult Self-Report Scale } \\
\text { - TDAH }\end{array}$ & (Kessler et al., 2005) & $\begin{array}{l}\text { Attention deficit } \\
\text { and hyperactivity } \\
\text { disorder }\end{array}$ & Patient & Adults & $\begin{array}{l}\text { (Mattos et al., } \\
\text { 2006) }\end{array}$ \\
\hline
\end{tabular}

The Cambridge Behavior Prospective Memory Test (CAMPROMPT; Wilson et al., 2005). This test includes time-based and event-based tasks such as reminding the examiner not to forget a key after a span of 15 minutes; asking the examiner for a newspaper after 20 minutes; moving to a second task for five minutes after working on a first task for 20 minutes; opening or closing a task booklet 3 minutes after the instructions are given; reminding the psychologist of five hidden objects after the test is finished; putting a briefcase under the table after an alarm sounds; changing pens after completing seven tasks; and delivering an envelope (with the word "message" written on it) to the psychologist when he/she says the patient has 10 minutes left to complete the task (Groot, Wilson, Evans, \& Watson, 2002).

\section{Ecological Assessment of EF in Children}

The neuropsychological assessment of EF in children is often performed using tools adapted from adult assessment instruments. One of the main limitations of this type of task is that the examiner acts as the child's executive control, orienting, organizing, and monitoring their performance, and sometimes even providing clues which may enhance and bias the child's responses to the task. Consequently, children may display adequate performance on both standardized formal tasks and ecological instruments, despite reporting several impairments in their daily functioning (Chevignard, Catroppa, Galvin, \& Anderson, 2010; Gioia \& Isquith, 2004; Toplak et al., 2013).

Some features also place additional limitations on the ecological validity of children's assessment instruments, such as the influence of biological, sociodemographic, and cultural factors on cognitive development (Ardila, Rosselli, Matute, \& Guajardo, 2005; Hackman \& Farah, 2013; Rueda, Rothbart, McCandliss, Saccomanno, \& Posner, 2005). For instance, performance on self-report instruments may depend on the child's ability to read, understand, and express themselves (Woolley, Bowen, \& Bowen, 2011).

On Table 3, neuropsychological tools used to assess EF in children are described. Instru- 
ments are classified into categories, and each tool is identified by means of a letter (from a to $\mathrm{k}$ ), according to the following system:

Functional instruments: Scales and questionnaires [Table 3, instruments (a) to (f)]: ask the parents, caregivers and /or teachers to evaluate the child's behavior in different contexts (Shimoni et al., 2012). Scales and questionnaires may be limited by biased responses and discrepancies between the information provided by parents and teachers, due to a lack of interinformant and inter-setting agreement (Chevignard et al., 2010).

Standardized instruments: Structured neuropsychological tests which simulate real-world situations [Table 3, (g) and (i)]. The most commonly cited such instrument is the Behavioral Assessment of Dysexecutive Syndrome for Chil- dren (Emslie, Wilson, Burden, Nimmo-Smith, \& Wilson, 2003).

Ecological instruments: Evaluate performance on tasks which simulate everyday situations [Table 3, (j) to $(\mathrm{k})$ ], by asking the child to perform specific routine activities (e.g., organizing school materials) or through behavioral observation protocols. Although it may difficult to establish objective criteria for the measurement of EF in children using ecological tools (Chevignard et al., 2010), such instruments can be very helpful in providing complementary information to that obtained from clinical observation.

The present review demonstrated a lack of ecological instruments for the assessment of EF in children (Chevignard et al., 2010). Thus, further investments in the adaptation and/or development of ecological measures for this population is required.

Table 3

Executive Functions Ecological Tasks for Children

\begin{tabular}{ll} 
Instruments & $\begin{array}{l}\text { Cognitive components } \\
\text { evaluated }\end{array}$ \\
\hline a) Behavioural Rating Inventory of & $\begin{array}{l}\text { Emotional control, } \\
\text { Executive Functions (BRIEF; Gioia, }\end{array}$ \\
\hline Isquith, Guy, \& Kenworthy, 2000) & $\begin{array}{l}\text { inhibition, initiation, } \\
\text { working memory, } \\
\text { planning, organization } \\
\text { and monitoring }\end{array}$
\end{tabular}

b) Dysexecutive Questionnaire for Children (DEX-C; Emslie et al., 2003)

c) Childhood Executive Functioning Inventory (CHEXI; Thorell \& Nyberg, 2008)

d) Children's Executive Functions Scale (CEFS; Silver, Kolitz-Russell, Bordini, \& Fairbanks, 1993)

e) The Attention and Executive Function Rating Inventory (Klenberg, Jamsa, Hayrinen, Lahti-Nuuttila, \& Korkman, 2010)

f) Behavioral Inhibition Questionnaire (Bishop, Spence, \& McDonald, 2003)

g) Behavioural Assessment of Dysexecutive Syndrome for Children (BADS-C; Emslie et al., 2003)
Cognitive, behavioral, and emotional problems associated with executive dysfunction

Inhibition, working memory, planning and regulation

Social adaptation, initiation, problem solving, motor planning

Inhibition, attention control Teachers and execution of actions

$\begin{array}{lll}\text { Parents } & 8 \text { to } 16 & \text { Not found } \\ \text { and } & \text { years-old } & \end{array}$

teachers

$\begin{array}{lll}\begin{array}{l}\text { Parents } \\ \text { and } \\ \text { teachers }\end{array} & \begin{array}{l}\text { Not } \\ \text { reported }\end{array} & \begin{array}{l}\text { (Trevisan, Dias, } \\ \text { Menezes, \& } \\ \text { Seabra, 2012) }\end{array} \\ \text { Parents } & \begin{array}{l}\text { School-age } \\ \text { children }\end{array} & \text { Not found }\end{array}$

No

reported Not found

Not

Shyness, fear and social Parents reported Not found isolation

Cognitive flexibility, 8 to 16 year-olds

Not found monitoring and organization 
h) Children Gambling Task (CGT; Decision making Kerr \& Zelazo, 2004)

i) Child-Kitchen Task Assessment (Rocke, Hays, Edwards, \& Berg, 2008)

j) School Assessment of Motor and Process Skills (School AMPS; Atchison, Fisher, \& Bryze, 1998)

k) Children's Cooking Task (M. P. Chevignard et al., 2008)
Initiation, judgment, organization, and planning

Motor and process skills

Initiation, monitoring, and planning
Adapted from the adult version to investigate decision making in children aged 3 to 4 years

8 to 12 year-olds

School-age children

8 to 14 year-olds

Not found

(Mata et al., 2010; Mata, Miranda, \& 2013)

Not found

Not found Sallum, Moraes, Malloy-Diniz,

\section{Implications of the Ecological Approach to Neuropsychological Rehabilitation}

The use of ecological tools to establish a neuropsychological diagnosis allows clinicians to better comprehend patient functioning in real life situations. The traditional assumption that simpler tasks allow for a more specific analysis of discrete cognitive functions (Lezak et al., 2012) does not apply to the construction and rationale behind ecological tasks. Therefore, performance on these instruments must be interpreted based on critical neuropsychological reasoning.

With regards to an ecological approach to neuropsychological rehabilitation, there appears to be very little literature on the efficacy and effectiveness of different methods. However, the importance of taking the client's natural environment into account during the rehabilitation process has been discussed in the literature for years. Wilson (2011) has suggested that neuropsychological rehabilitation must emphasize daily activities rather than standardized training protocols, which have been shown by several studies to lead to a poor generalization of therapeutic results. A recent systematic review of the efficacy of different assessment instruments in evaluating the results of evidence-based neuropsychological programs has also suggested that formal assessment tools may not be reliable in identifying functional improvements in the patient's daily life. Therefore, the authors suggest- ed that ecological assessment tools be used for the assessment of the efficacy of different neuropsychological rehabilitation programs (Loschiavo-Alvares et al., 2011).

In a similar vein, Walker et al. (2012) performed a randomized controlled trial assessing the effects of an ecological neuropsychological training program and of a conventional training protocol on the dressing ability of acute stroke patients. Improvements in dressing ability were observed in both groups. Additionally, improvements in visual hemineglect (line cancellation and gesture praxis) were observed following treatment in the ecological rehabilitation group, especially in patients with right brain damage. Such findings suggest that ecological neuropsychological approaches may have different effects from those of other types of rehabilitation approaches, such as occupational therapy training. In spite of the wealth of evidence supporting the efficacy of rehabilitation programs with cognitivetraining approach (Fish et al., 2007; Levine et al., 2000), there does not appear to be sufficient data in the literature regarding the specific effects of different approaches available.

\section{Functional Neuroimaging and the Ecological Approach}

The ecological approach to neuropsychological assessment and rehabilitation has clear and promising implications to both clinical and research settings. However, even further evi- 
dence of the importance of such an approach has been obtained by studies involving both neuroradiology and neuropsychological methods. Although there are some issues associated with dispensing with traditional experimental paradigms and subtraction methods, the use of an ecological approach to neuroimaging may also offer a new perspective on extensively discussed topics in neuropsychology.

For instance, Astolfi et al. (2010) investigated cortical activity during social interaction tasks using electroencephalography. The authors revealed differences in the areas activated in the brains of individuals completing different conditions of the task, making a promising contribution to the comprehension of social behavior. Similarly, Yalachkov, Kaiser and Naumer (2012) presented a review of brain activation during uni- and multisensory paradigms in individuals with substance addiction disorders. Results indicated that a greater correlation between brain activation and clinical variables was observed in response to multisensory cues rather than unisensory ones, demonstrating the relevance of the former in identifying relationships between behavior and the activation of neural networks associated with the symptoms of substance addiction. In summary, in spite of the low number of studies on this topic, it is possible to infer that the use of ecological tasks may decrease the artificial nature of neuroimaging studies. Additionally, the identification of closer relationships between target-situations and the activation of specific brain areas may help to advance theories of EF.

\section{Final Conclusions}

The increased interest and investment in the use of ecological tools for the assessment of EF may consist of an additional step toward the applicability of EF in neuropsychological science. In addition to contributing to both neuropsychological assessment and rehabilitation, the use of ecological tools may also enhance the applicability of functional neuroimaging studies, although further investigations performed by multidisciplinary teams are still required to confirm this hypothesis.
One of the main challenges of the use of ecological tasks in neuropsychological assessment is the development of adequate administration, scoring, and interpretation procedures, such as those available for standardized formal tasks, which are based on cognitive theories and psychometric criteria. These aspects must be kept in mind when developing or studying ecological instruments. However, the successful development of such procedures may eventually allow for more accurate cognitive diagnoses and for more reliable means of assessing the outcomes of neuropsychological interventions.

\section{References}

Alderman, N., Burgess, P. W., Knight, C., \& Henman, C. E. (2003). Ecological validity of a simplified version of the multiple errands shopping test. Journal of the International Neuropsychological Society, 9(1), 31-44.

Ances, B. M., Ortega, M., Vaida, F., \& Heaps, J. (2013). Independent effects of HIV, aging, and HAART on brain volumetric measures. Journal of Acquired Immune Deficiency Syndrome, 59(5), 469-477. doi:10.1097/QAI.0b013e318249db17. Independent

Appenzeller, S., Faria, A., Marini, R., Costallat, L. T. L., \& Cendes, F. (2006). Focal transient lesions of the corpus callosum in systemic lupus erythematosus. Clinical Rheumatology, 25(4), 568-571. doi:10.1007/s10067-005-0174-1

Ardila, A., Rosselli, M., Matute, E., \& Guajardo, S. (2005). The influence of the parents' educational level on the development of executive functions. Developmental Neuropsychology, 28(1), 539560. doi:10.1207/s15326942dn2801_5

Astolfi, L., Cincotti, F., Mattia, D., De Vico Fallani, F., Salinari, S., Vecchiato, G., ...Babiloni, F. (2010). Simultaneous estimation of cortical activity during social interactions by using EEG hyperscannings. Conference Proceedings : Annual International Conference of the IEEE Engineering in Medicine and Biology Society, 28142817. doi:10.1109/IEMBS.2010.5626555

Atchison, B., Fisher, A., \& Bryze, K. (1998). Rater reliability and internal scale and person response validity of the school assessment of motor and process skills. American Journal of Occupational Therapy, 52, 843-850. 
Bahia, V. S., Silva, M. M., Viana, R., Smid, J., Damin, A. E., \& Radanovic, M. (2008). Behavioral and activities of daily living inventories in the diagnosis of frontotemporal lobar degeneration and Alzheimer's disease. Dementia \& Neuropsychologia, 2(2), 108-113.

Barkley, R. A. (2012). Executive functions: What they are, how they work, and why they evolved. New York: Guilford Press.

Bechara, A. (2007). Iowa Gambling Task: Professional manual. Lutz, FL: Psychological Assessment Resources.

Bechara, A., Damasio, A., Damasio, H., \& Anderson, S. (1994). Insensitivity to future consequences following damage to human prefrontal cortex. Cognition, 50, 7-15.

Belleville, S., Rouleau, N., \& Van der Linden, M. (2006). Use of the Hayling task to measure inhibition of prepotent responses in normal aging and Alzheimer's disease. Brain and Cognition, 62(2), 113-119. doi:10.1016/j. bandc.2006.04.006

Benites, D., \& Gomes, W. B. (2007). Tradução, adaptação e validação preliminar do Prospective and Retrospective Memory Questionnaire (PRMQ). Psico-USF, 12(1), 45-54.

Bishop, G., Spence, S. H., \& McDonald, C. (2003). Can parents and teachers provide a reliable and valid report of behavioral inhibition? Child Development, 74, 1899-1917.

Brunswik, E. (1955). Representative design and probabilistic theory in a functional psychology. Psychological Review, 62(3), 193-217. doi:10.1037/h0047470

Burgess, P. W., Alderman, N., Forbes, C., Costello, A., Coates, L. M., Dawson, D. R., ...Channon, S. (2006). The case for the development and use of "ecologically valid" measures of executive function in experimental and clinical neuropsychology. Journal of the International Neuropsychological Society, 12(2), 194-209. doi:10.1017/S1355617706060310

Cardoso, C. O., Branco, L., Cotrena, C., \& Fonseca, R. P. (2013). Adaptação do Questionário Melbourn de Tomada de Decisão para o português brasileiro [Resumo]. Trends in Psychiatry and Psychotherapy, 35(3, Supl.), S22.

Cardoso, C. O., Carvalho, J. C., Cotrena, C., BakosSchneider, D., Kristensen, C., \& Fonseca, R. (2010). Estudo de fidedignidade do instrumento neuropsicológico Iowa Gambling Task. Jornal Brasileiro de Psiquiatria, 59(4), 279$285 . \quad$ doi:http://dx.doi.org/10.1590/S004720852010000400003

Cardoso, C. O., Zimmermann, N., Paraná, C. B., Gindri, G., De Almeida, A. P. P., \& Fonseca, R. P. (2013). Desenvolvimento de uma versão brasileira da Tarefa do Hotel: Um instrumento de avaliação ecológica das funções executiva. In Anais do VI Congresso Brasileiro de Avaliação Psicológica. Recuperado em http://www.ibapnet. org.br/congresso2013/lista_trabalhos_poster.php

Carim, D., Miranda, M., \& Bueno, O. (2012). Tradução e adaptação para o português do Behavior Rating Inventory of Executive Function - BRIEF. Psicologia: Reflexão e Crítica, 25(4), 653-661. doi:10.1590/S0102-79722012000400004

Carvalho, J. C. N., Cardoso, C. O., Cotrena, C., BakosSchneider, D. G., Kristensen, C. H., \& Fonseca, R. P. (2012). The effect of age on decision making according to the Iowa Gambling task. The Spanish Journal of Psychology, 15(2), 480-486.

Carver, C. S., \& White, T. L. (1994). Behavioral inhibition, behavioral activation, and affective responses to impending reward and punishment: The BIS/BAS scales. Journal of Personality and Social Psychology, 67(2), 319-333.

Chan, R. C. K., Shum, D., Toulopoulou, T., \& Chen, E. Y. H. (2008). Assessment of executive functions: Review of instruments and identification of critical issues. Archives of Clinical Neuropsychology, 23, 201-216. doi:10.1016/j. acn.2007.08.010

Chaytor, N., \& Schmitter-Edgecombe, M. (2003). The ecological validity of neuropsychological tests: A review of the literature on everyday cognitive skills. Neuropsychology Review, 13(4), 181-197. Retrieved from http://www.ncbi.nlm. nih.gov/pubmed/15000225

Chaytor, N., \& Schmitter-Edgecombe, M. (2007). Fractionation of the dysexecutive syndrome in a heterogeneous neurological sample: Comparing the Dysexecutive Questionnaire and the Brock Adaptive Functioning Questionnaire. Brain Injury, 21(6), 615-621. doi:10.1080/02699050701426949

Chaytor, N., Schmitter-Edgecombe, M., \& Burr, R. (2006). Improving the ecological validity of executive functioning assessment. Archives of Clinical Neuropsychology, 21(3), 217-227. doi:10.1016/j.acn.2005.12.002 
Chevignard, M., Catroppa, C., Galvin, J., \& Anderson, V. (2010). Development and evaluation of an Ecological Task to Assess Executive Functioning Post Childhood TBI: The Children's Cooking Task. Brain Impairment, 11(2), 125143. doi:10.1375/brim.11.2.125

Chevignard, M. P., Taillefer, C., Picq, C., Poncet, F., Noulhiane, M., \& Pradat-Diehl, P. (2008). Ecological assessment of the dysexecutive syndrome using execution of a cooking task. Neuropsychological Rehabilitation, 18(4), 461-485. doi:10.1080/09602010701643472

Crook, T. H., Feher, E. P., \& Larrabee, G. J. (1992). Assessment of memory complaints in age-associated memory impairment: The MAC. International Psychogeriatry, 4, 165-176.

Cubelli, R. (2005). The history of neuropsychology according to Norman Geschwind: Continuity and discontinuity in the development of science. Cortex, 41, 271-274. doi:10.1016/S00109452(08)70913-4

Cuberos-Urbano, G., Caracuel, A., Bateman, A., Vilar-López, R., \& Verdejo-García, A. (2013). Ecological validity of the Multiple Errands Test using predictive models of dysexecutive problems in everyday life Ecological validity of the Multiple Errands Test using predictive models of dysexecutive. Journal of Clinical and Experimental Neuropsychology, 35(3), 37-41. doi:10.1 080/13803395.2013.776011

Diamond, A. (2013). Executive functions. Annual Review of Psychology, 64, 135-168. doi:10.1146/ annurev-psych-113011-143750

Emslie, H., Wilson, C., Burden, V., Nimmo-Smith, I., \& Wilson, B. (2003). Behavioural Assesment of Dysexecutive Syndrome for Children (BADS-C). Titchfield, UK: Thames Valley Tests Company.

Fish, J., Evans, J. J., Nimmo, M., Martin, E., Kersel, D., Bateman, A., ...Manly, T. (2007). Rehabilitation of executive dysfunction following brain injury: "Content-free" cueing improves everyday prospective memory performance. Neuropsychologia, 45(6), 1318-1330. doi:10.1016/j. neuropsychologia.2006.09.015

Fonseca, R. P., Zimmermann, N., Pawlowski, J., Oliveira, C. R., Gindri, G., Scherer, L. C., ... Parente, M. A. M. P. (2012). Métodos em avaliação neuropsicológica. In J. Landeira-Fernandez \& S. S. Fukusima (Eds.), Métodos em avaliação neuropsicológica (pp. 266-296). São Paulo, SP: Manole.
Gioia, G. A., \& Isquith, P. K. (2004). Ecological assessment of executive function in traumatic brain injury. Developmental Neuropsychology, 25(1-2), 135-158. doi:10.1080/87565641.2004. 9651925

Gioia, G., Isquith, P., Guy, S., \& Kenworthy, L. (2000). Behavior Rating Inventory of Executive Function. Odessa, FL: Psychological Assessment Resources.

Groot, Y. C. T., Wilson, B. A., Evans, J., \& Watson, P. (2002). Prospective memory functioning in people with and without brain injury. Journal of the International Neuropsychological Society, 8(5), 645-654. Retrieved from http://www.ncbi. nlm.nih.gov/pubmed/12164674

Hackman, D. A., \& Farah, M. J. (2013). Socioeconomic status and the developing brain. Trends in Cognitive Sciences, 13(2), 65-73. doi:10.1016/j. tics.2008.11.003.Socioeconomic

Hartman-Maeir, A., \& Katz, N. (1995). Validity of the Behavioral Inattention Test (BIT): Relationships with functional tasks. The American Journal of Occupational Therapy, 49(6), 507-516.

Kerr, A., \& Zelazo, P. D. (2004). Development of "hot" executive function: The children's gambling task. Brain and Cognition, 55(1), 148-157. doi:10.1016/S0278-2626(03)00275-6

Kertesz, A., Davidson, W., \& Fox, H. (1997). Frontal behavioral inventory: Diagnostic criteria for frontal lobe dementia. Canadian Journal of Neurological Sciences, 24(1), 29-39.

Kessler, R. C., Adler, L., Ames, M., Delmer, O., Faraone, S., Hiripi, E., ... Walters, E. E. (2005). The World Health Organization Adult ADHD SelfReport Scale (ASRS): A short screening scale for use in the general population. Psychological Medicine, 35, 245-256.

Klenberg, L., Jamsa, S., Hayrinen, T., Lahti-Nuuttila, P., \& Korkman, M. (2010). The Attention and Executive Function Rating Inventory (ATTEX): Psychometric properties and clinical utility in diagnosing ADHD subtypes. Scandinavian Journal of Psychology, 51, 439-448. doi:10.1111/j.1467-9450.2010.00812.x

Knight, C., Alderman, N., \& Burgess, P. W. (2002). Development of a simplified version of the Multiple Errands Test for Use in Hospital Settings. Neuropsychological Rehabilitation, 12, 231255. doi:10.1080/09602010244000039 
Koerts, J., van Beilen, M., Leenders, K. L., Brouwer, W. H., Tucha, L., \& Tucha, O. (2012). Complaints about impairments in executive functions in Parkinson's disease: The association with neuropsychological assessment. Parkinsonism \& Related Disorders, 18(2), 194-197. doi:10.1016/j.parkreldis.2011.10.002

Kounti, F., Tsolaki, M., \& Kiosseoglou, G. (2006). Functional cognitive assessment scale (FUCAS): A new scale to assess executive cognitive function in daily life activities in patients with dementia and mild cognitive impairment. Human Psychopharmacology, 21(5), 305-311. doi:10.1002/hup.772

Levine, B., Robertson, I. H., Clare, L., Carter, G., Hong, J., Wilson, B. A., ...Stuss, D. T. (2000). Rehabilitation of executive functioning: An experimental-clinical validation of goal management training. Journal of the International Neuropsychological Society, 6(3), 299-312. Retrieved from http://www.ncbi.nlm.nih.gov/ pubmed/10824502

Lezak, M. D., Howieson, D. B., Bigler, E. D., \& Tranel, D. (Eds.). (2012). Neuropsychological Assessment $\left(5^{\text {th }}\right.$ ed.). New York: Oxford University Press.

Lorch, M. (2011). Re-examining Paul Broca's initial presentation of M. Leborgne: Understanding the impetus for brain and language research. Cortex, 47(10), 1228-1235. doi:10.1016/j.cortex.2011.06.022

Loschiavo-Alvares, F. Q., Yumi, C., Sediyama, N., Rivero, T. S., Nicolato, R., Bueno, O. F. A., ... Malloy-Diniz, L. F. (2011). Tools for efficacy's assessment of neuropsychological rehabilitation programs: A systematic review. Clinical Neuropsychiatry, 8(3), 1-11.

Macuglia, G. C. R., Rossatto, F. C., Almeida, R. M. M., \& Giacomoni, C. (2012). Adaptação cultural e validação da bateria de avaliação de funções executivas Behavioural Assessment of the Dysexecutive Syndrome (BADS) [Resumo]. In Anais da III Reunião Anual do IBNeC (p. 281). Florianópolis, SC: Instituto Brasileiro de Neuropsicologia e Comportamento.

Malloy-Diniz, L. F., Leite, W. B., Moraes, P. H., Correa, H., Bechara, A., \& Fuentes, D. (2008). Brazilian Portuguese version of Iowa Gambling Task (IGT): Transcultural adaptation and discriminant validity. Revista Brasileira de Psiquiatria, 30(2), 144-148.
Manly, T., Hawkins, K., Evans, J., Woldt, K., \& Robertson, I. H. (2002). Rehabilitation of executive function: Facilitation of effective goal management on complex tasks using periodic auditory alerts. Neuropsychologia, 40(3), 271-281. Retrieved from http://www.ncbi.nlm.nih.gov/ pubmed/11684160

Mann, L., Burnett, P., Radford, M., \& Ford, S. (1997). The Melbourne Decision Making Questionnaire: An instrument for measuring patterns for coping with decisional conflict. Journal of Behavioral Decision Making, 10, 1-19.

Marshall, J. C., \& Fink, G. R. (2003). Cerebral localization, then and now. NeuroImage, 20(Suppl. 1), S2-S7. doi:10.1016/j.neuroimage.2003.09.001

Mata, F., Moraes, P. H., Campos, A., Leite, W., Fuentes, D., \& Malloy-Diniz, L. (2010). Children Gambling Task. In L. F. Malloy-Diniz, D. Fuentes, P. Mattos, \& N. Abreu (Eds.), Avaliação neuropsicológica (pp. 378-381). Porto Alegre, RS: Artmed.

Mata, F., Sallum, I., Moraes, P. H., Miranda, D. M., \& Malloy-Diniz, L. (2013). Development of a computerised version of the Children's Gambling Task for the evaluation of affective decision-making in Brazilian preschool children. Estudos de Psicologia (Natal), 18(1), 151-157. doi:10.1590/S1413-294X2013000100024

Mattos, P., Lino, V., Rizo, L., Alfano, A., Araújo, C., \& Raggio, R. (2003). Memory complaints and test performance in healthy elderly persons. $A r$ quivos de Neuropsiquiatria, 61(4), 920-924.

Mattos, P., Segenreich, D., Saboya, E., Louzã, M., Dias, G., \& Romano, M. (2006). Adaptação transcultural para o português da escala Adult Self-Report Scale para avaliação do transtorno de déficit de atenção/hiperatividade (TDAH) em adultos. Revista de Psiquiatria Clínica, 33(4), 88-194.

Oliveira, R., \& Schmidt, S. L. (1999). Teste Comportamental de Memória de Rivermead: Manual da versão traduzida e adaptada para o Brasil. Rio de Janeiro, RJ: Cognição.

Peña-Casanova, J., Quiñones-Ubeda, S., GramuntFombuena, N., Quintana, M., Aguilar, M., Molinuevo, J. L., ...Blesa, R. (2009). Spanish Multicenter Normative Studies (NEURONORMA Project): Norms for the Stroop color-word interference test and the Tower of London-Drexel. Archives of Clinical Neuropsychology, 24(4), 


\section{3-429. doi:10.1093/arclin/acp043}

Periáñez, J. A., Ríos-Lago, M., Rodríguez-Sánchez, J. M., Adrover-Roig, D., Sánchez-Cubillo, I., Crespo-Facorro, B., ...Barceló, F. (2007). Trail Making Test in traumatic brain injury, schizophrenia, and normal ageing: Sample comparisons and normative data. Archives of Clinical Neuropsychology, 22(4), 433-447. doi:10.1016/j.acn.2007.01.022

Prigatano, G. P. (1986). Neuropsychological rehabilitation after brain injury. Baltimore, MD: Johns Hopkins University Press. Retrieved from http:// www.getcited.org/pub/102447839

Robertson, I. H., Ward, T., Ridgeway, V., \& NimmoSmith, I. (1994). The Test of Everyday Attention manual. Bury, UK: Thames Valley Test Company.

Rocke, K., Hays, P., Edwards, D., \& Berg, C. (2008). Development of a performance assessment of executive function: The Children's Kitchen Task Assessment. American Journal of Occupational Therapy, 62(5), 528-537.

Rueda, M. R., Rothbart, M. K., McCandliss, B. D., Saccomanno, L., \& Posner, M. I. (2005). Training, maturation, and genetic influences on the development of executive attention. Proceedings of the National Academy of Sciences of the United States of America, 102(41), 1493114936. doi:10.1073/pnas.0506897102

Sbordone, R. J. (2010). Neuropsychological Tests are poor at assessing the frontal lobes, executive functions, and neurobehavioral symptoms of traumatically brain-injured patients. Psychological Injury and Law, 3(1), 25-35. doi:10.1007/ s12207-010-9068-x

Schneider, D., \& Parente, M. (2006). O desempenho de adultos jovens e idosos na Iowa GamblingTask (IGT): Um estudo sobre a tomada de decisão. Psicologia: Reflexão e Crítica, 19(3), $442-450$.

Shallice, T., \& Burgess, P. W. (1991). Deficits in strategy application following frontal lobe damage in man. Brain, 727-741.

Shimoni, M., Engel-Yeger, B., \& Tirosh, E. (2012). Executive dysfunctions among boys with Attention Deficit Hyperactivity Disorder (ADHD): Performance-based test and parents report. Research in Developmental Disabilities, 33(3), 858-865. doi:10.1016/j.ridd.2011.12.014
Silver, C. H., Kolitz-Russell, S., Bordini, F., \& Fairbanks, J. (1993). The Children's Executive Functions Scale. Unpublished manuscript.

Smith, G., Sala, D. S., Logie, R., \& Maylor, E. A. (2000). Prospective and retrospective memory in normal aging and dementia: A questionnaire study. Memory, 8(5), 311-321.

Spikman, J. M., Hol-Steegstra, A., Rietberg, H., Vos, S., Boelen, D., \& Lamberts, K. F. (2007). The Executive Secretariat Task (EST): A real-life, ecologically valid measurement of executive functioning. Brain Impairment, 8, 223.

Stuss, D. T., \& Alexander, M. P. (2007). Is there a dysexecutive syndrome? Philosophical Transactions of the Royal Society of London. Series B, Biological Sciences, 362(1481), 901-915. doi:10.1098/rstb.2007.2096

Sunderland, A., Harris, J. E., \& Baddeley, A. D. (1983). Do laboratory tests predict everyday memory? A neuropsychological study. Journal of Verbal Learning and Verbal Behavior, 22, 727-738.

Thorell, L. B., \& Nyberg, L. (2008). The Childhood Executive Functioning Inventory (CHEXI): A new rating instrument for parents and teachers. Developmental Neuropsychology, 33, 536-552.

Toplak, M. E., West, R. F., \& Stanovich, K. E. (2013). Practitioner review: Do performancebased measures and ratings of executive function assess the same construct? Journal of Child Psychology and Psychiatry, and Allied Disciplines, 54(2), 131-143. doi:10.1111/jcpp.12001

Trevisan, B. T., Dias, N. M., Menezes, A., \& Seabra, A. G. (2012). The Brazilian version of the Childhood Executive Functioning Inventory (CHEXI) for evaluation of children with ADHD [Resumo]. In Annals of European Network of Hyperkinetic Disorders $2^{\text {nd }}$ International ADHD Conference: Sharpening the cutting edge of ADHD Science and Clinical Practice (p. 176). Barcelona, Spain: European Network of Hyperkinetic Disorders International Conferences.

Tun, P. A., \& Wingfield, A. (1995). Does dividing attention become harder with age? Findings from the Divided Attention Questionnaire. Aging and Cognition, 2, 39-66.

Verdejo-García, A., \& Tirapu-Ustárroz, J. (2012). Neuropsicología clínica en perspectiva: retos futuros basados en desarrollos presentes. Revista de Neurología, 54(3), 180-186. 
Walker, M. F., Sunderland, A., Fletcher-Smith, J., Drummond, A., Logan, P., Edmans, J. A, ... Taylor, J. L. (2012). The DRESS trial: A feasibility randomized controlled trial of a neuropsychological approach to dressing therapy for stroke inpatients. Clinical Rehabilitation, 26(8), 675-685. doi:10.1177/0269215511431089

Wilson, B. A. (2011). "Cutting Edge" developments in neuropsychological rehabilitation and possible future directions. Brain Impairment, 12(1), 33-42. doi:10.1375/brim.12.1.33

Wilson, B. A., Alderman, N., Burgess, P. W., Emslie, H., \& Evans, J. J. (1996). Behavioural assessment of the dysexecutive syndrome. Bury, UK: Thames Valley Test Company.

Wilson, B. A., Clare, L., Baddeley, A. D., Cockburn, J., Watson, P., \& Tate, R. L. (1999). The Rivermead Behavioural Memory Test - Extended version. Bury, UK: Thames Valley Test Company.

Wilson, B. A., Cockburn, J., \& Baddeley, A. (1985). The Rivermead Behavioral Memory Test. Bury, UK: Thames Valley Test Company.

Wilson, B. A., Cockburn, J., \& Halligan, P. W. (1987). Behavioral Inattention Test. Fareham, UK: Thames Valley Test Company.

Wilson, B. A., Emslie, H., Foley, J., Shiel, A., Watson, P., Hawkins, K., ...Evans, J. J. (2005). The Cambridge Prospective Memory Test. London. London: Harcourt Assessment.

Witsken, D., D’Amato, R. C., \& Hartlage, L. C. (2008). Understanding the past, present, and future of clinical neuropsychology. In R. C. D'Amato \& L. C. Hartlage (Eds.), Essentials of neuropsychological assessment: Rehabilitation planning for intervention (pp. 1-30). New York: Springer.
Wood, R. L., \& Liossi, C. (2006). The ecological validity of executive tests in a severely brain injured sample. Archives of Clinical Neuropsychology, 21(5), 429-437. doi:10.1016/j.acn.2005.06.014

Woolley, M. E., Bowen, G. L., \& Bowen, N. K. (2011). Cognitive pretesting and the developmental. Research on Social Work Practice, 14(3), 191-200. doi:10.1177/1049731503257882

Yalachkov, Y., Kaiser, J., \& Naumer, M. J. (2012). Functional neuroimaging studies in addiction: Multisensory drug stimuli and neural cue reactivity. Neuroscience and Biobehavioral Reviews, 36(2), 825-835. doi:10.1016/j.neubiorev.2011.12.004

Yassuda, M. S., Flaks, M. K., Viola, L. F., Pereira, F. S., Memória, C. M., Nunes, P. V., \& Forlenza, O. (2010). Psychometric characteristics of the Rivermead Behavioural Memory Test (RBMT) as an early detection instrument for dementia and mild cognitive impairment in Brazil. International Psychogeriatrics, 22(6), 1003-1011. doi:10.1017/S1041610210001055

Zimmermann, N., de Pereira, A. P. A., \& Fonseca, R. P. (2014). Brazilian Portuguese version of the Patient Competency Scale (PCRS-R-BR): Semantic adaptation and validity. Trends in Psychiatry and Psychotherapy, 36(1), 1-8. doi:http://dx.doi. org/10.1590/2237-6089-2013-0021

Received: April, 29, 2013

$1^{\text {st }}$ revision: October, 03, 2013

$2^{\text {nd }}$ revision: January, 07, 2014

$3^{\text {rd }}$ revision: May, 08, 2014

Accepted: May, 14, 2014 